\title{
Cultura Cultura
}

\section{ARAÚJO, Ana Cristina, A Cultura das Luzes em Portugal, Temas e Problemas}

\section{Nuno Martins}

\section{(2) OpenEdition}

1 Journals

\section{Edição electrónica}

URL: http://journals.openedition.org/cultura/912

DOI: 10.4000/cultura.912

ISSN: 2183-2021

\section{Editora}

Centro de História da Cultura

\section{Edição impressa}

Data de publição: 1 junho 2007

Paginação: 281-285

ISSN: 0870-4546

\section{Refêrencia eletrónica}

Nuno Martins, "ARAÚJO, Ana Cristina, A Cultura das Luzes em Portugal, Temas e Problemas », Cultura

[Online], Vol. 24 | 2007, posto online no dia 10 outubro 2013, consultado a 22 setembro 2020. URL : http://journals.openedition.org/cultura/912 ; DOI : https://doi.org/10.4000/cultura.912 


\title{
ARAÚJo, Ana Cristina, A Cultura das Luzes em Portugal, Temas e Problemas, Lisboa, Livros Horizonte, 2003, 126 pp.
}

\author{
Nuno Martins
}

Inserido na colecção Temas de História de Portugal, cujo objectivo, balizado pelos seus coordenadores, Isabel Cluny e Nuno Gonçalo Monteiro, é "colocar à disposição dos leitores interessados textos sintéticos, mas actualizados, sobre grandes temas da História de Portugal", A Cultura das Luzes em Portugal, Temas e Problemas é um ensaio-síntese da autoria de Ana Cristina Araújo e pretende gizar uma análise interpretativa da permeabilidade do espaço cultural português às novas correntes filosóficas de pensamento associadas ao período das Luzes, em articulação com as singularidades da recepção, assimilação e reprodução próprias no espaço cultural de Portugal na centúria de Setecentos.

Ana Cristina Araújo, reputada investigadora e autora de estudos centrados na problematização da época das Luzes em Portugal, é professora da Faculdade de Letras na Universidade de Coimbra, membro do Instituto de História e Teoria das Ideias, investigadora do Centro de História da Sociedade e da Cultura e redactora da Revista de História das Ideias.

Com frequência, uma leitura e apreensão menos atenta da globalidade dos estímulos implícitos às correntes filosóficas emergentes no século XVIII, associada à representação do lluminismo, como fenómeno global, uno e de difusão transparente, conduz à ideia de que as Luzes se acenderam na Europa do século XVIII, de um centro peninsular até às periferias, onde Portugal ocuparia uma posição de receptor tardio. Nada mais errado.

A presente obra proporciona visibilidade ao impacto do novo pensamento produzido além-fronteiras, às repercussões numa elite erudita nacional que, desta forma, descobria uma ignição para discutir o ideário de pensar a natureza, o homem, a política e a organização social. Assimilando essas ideias, mas não sendo mero receptáculo, procurando criticá-las objectivamente, produzindo e teorizando num frenesim clandestino que se estendeu e contaminou os círculos eruditos, adquiriu uma dimensão à qual as forças dominantes da sociedade portuguesa responderam, em diferentes momentos, de diferentes formas e com diferentes recursos.

Ana Cristina Araújo transporta o leitor para o plano das ideias, para o palco dos novos espaços de sociabilidade e discussão intelectual, não obedecendo a uma lógica cronológica, porque uma exposição temporal e factual não é a sua intenção. E ainda bem. Importa- 
-Ihe sim, oferecer uma interpretação da conjuntura nacional face ao pensamento europeu, da postura do Estado e do clero face a uma renovada epistéme, do processamento interno das diversas correntes filosóficas e da sua repercussão e reprodução, visitando os espaços físicos e mentais de fermentação de uma modernidade nacional. Todo este manancial de intenções é substantivo e claramente problematizado em A Cultura das Luzes em Portugal, explorando os estádios de consenso e contradição que a enformam.

Para este fim, a autora dividiu o livro em dois blocos, Modernidade Cultural e Mentalidade Barroca e Cosmopolitismo e Opinião Pública, precedidos de uma longa introdução, onde se manifestam os postulados da reflexão. O resultado é uma construção intelectual num espaço analítico onde, primeiramente, se expõem e traçam as singularidades que distinguiram os diferentes níveis de aquisição e cruzamento de uma anunciada modernidade intelectual por oposição, complemento e transformação a uma mentalidade barroca dominante nas esferas do poder, insegura e caduca. Na segunda parte, aborda-se concretamente o que foi a cultura das Luzes em Portugal, as reacções e tensões geradas, os meios e suportes de difusão, a emergência de espaços públicos, a divulgação directa enlevada na produção cultural ou na subtileza dos discursos, a difusão de objectos culturais, a profusão de livros proibidos em circulação, a apetência de um público cada vez mais vasto, os instrumentos de repressão e controlo censório do Estado.

As preocupações subjacentes à organização da primeira parte do livro, prendem-se com a identificação de campos ideológicos, várias vezes antagónicos, mas também cúmplices e coexistentes. A percepção dos antigos pelos modernos no período inicial da modernidade é delineada na evidência da permeabilidade às modernas teorias na esfera do conhecimento, principalmente nos domínios da Física, da Astronomia e da Matemática. Os modernos "descobriram" a racionalidade como fundamento da verdade científica, cuja centralidade é intrínseca aos métodos propostos pela vanguarda do pensamento europeu, com princípios submissos a propostas de interpretação da natureza e do mundo em eixos diferenciados. O método cartesiano, da razão pura, ou o método de Newton, mecanicista, reflectiam a dificuldade de interpretação do presente para o homem do século XVIII e de entendimento das leis da natureza, que lhe confiava, aos poucos, os seus mais profundos segredos. Em Portugal, contrariamente à ideia de uma retardatária e periférica recepção das novidades estrangeiras, esta múltipla assunção de escrutínio do mundo era quase em simultâneo descoberta, recepcionada e apreendida com actualidade, apesar das limitações de alcance, objecto de reflexões em privado e em pequenos grupos, discutida pelos primeiros modernos, factor de uma progressiva evolução do pensamento.

A confiança na lógica natural, na razão natural e no empirismo, precedida por uma submissão à Geometria de toda a percepção da natureza e das noções apreendidas pelos 
sentidos, são as tendências que se prefiguram no caminho do domínio do conhecimento em defesa da liberdade de pensamento.

E quem foram estes modernos? Que dilemas se lhes depararam no confronto das novas ideias com o pensamento escolástico instituído e enraizado no ontos? Que compromissos assumiram ou permitiram, consciente e inconscientemente, perante o dilema do alinhamento com a moral oficial de forma a não chocar com as posições escolásticas? O choque dos paradigmas mecanicista de Newton, racionalista de Descartes ou empirista de Locke, com os dogmas da fé, irredutivelmente defendidos pelos jesuítas, garantes da filosofia católica, proporcionou o aceso debate entre o aristotelismo escolástico e os novos sistemas filosóficos.

A estruturação de uma nova gnose, pela introdução de novos vocábulos na língua portuguesa, oriundos dos campos da Filosofia e do experimentalismo; pelas técnicas cartesianas, sustentáculo da razão pura e da ciência experimental; pela Geometria, vórtice e sustento do conhecimento; pela modernização do ensino das matérias científicas e dos modelos de saber; pelos estudos gramaticais e lexicográficos, e da função da palavra, numa problemática filosófica de nexo com a fé instituída, é explorada por Ana Cristina Araújo, numa visualização do caminho para uma modernidade pelo rompimento com o logos barroco.

Ao leitor é proporcionado um contacto superficial, mas significativo e substantivo, com a produção escrita que progressivamente emerge da fermentação das ideias no seio das elites eruditas nacionais. Importantes obras como a Logica Racional, Geometrica e Analitica (1744), de Manuel de Azevedo Fortes, apesar da evidente auto-censura, como salvaguarda do impacto na ruptura epistemológica, aliada a um temor em desafiar os primados do todo-poderoso catolicismo vigente na sociedade portuguesa de setecentos, são vigorosos testemunhos de uma transformação de ideias, propostas de debate e objectos de divulgação que, paulatinamente, estruturavam um desiderato para a modernidade, apesar das griIhetas da Igreja cuja resistência ao reconhecimento metodológico do experimentalismo e do empirismo, aos primeiros trabalhos de compendiação e outros contributos avulsos, era uma realidade que adquiria um sentido cada vez mais forte. Uma corrente anti-modernista coexistia, surda mas eficaz, e a sua face visível era denunciada pelo bloqueio à publicação de obras científicas estrangeiras em Portugal.

Esta dupla realidade, num complexo e intricado jogo entre as instituições do poder, complacentes por vezes, promotoras, noutras, ou ainda censórias e repressivas, com o meio dos pensadores modernistas, é explorada pela autora, para se poder apreender o clima das Luzes em Portugal, o impacto na sociedade, os mecanismos promotores ou bloqueadores, que potenciaram ou inibiram, que favoreceram ou antagonizaram. Mas era peremptório e 
indisfarçável que a penetração era uma realidade e que a filosofia das Luzes, ou a linguagem dos sentidos, adquiriu uma dinâmica que dificilmente se deteria.

A abertura do espírito dos grandes do Reino vai produzindo efeitos, sobretudo nas gerações mais novas, e obras como o Verdadeiro Método de Estudar para ser útil à República e à Igreja (1746), de Luís António Verney, trouxeram para o domínio público novas ideias que punham em causa a mentalidade barroca e assumiam a ruptura com a escolástica instituída.

O inelutável trilhar do progresso da razão e das artes, do optimismo científico dos filósofos, conduz à ascensão de um novo homem, intelectual e moralmente, no despertar da civilidade dos povos e das nações. Este é o eixo axial para a segunda parte do livro. Se, antes, a essência é a descoberta, recepção, assimilação e produção própria do pensamento das Luzes, agora, a autora expõe a própria cultura das Luzes no palco português.

As reformas do ensino, os meios de divulgação, os mecanismos editoriais, as práticas culturais, a relação com os poderes censórios são agora expostos, sintética mas sistematizadamente. A Educação, sustentada pela Filosofia, é factor primordial de civilização e, transportada numa matriz cristã de aperfeiçoamento do género humano, deveria promover uma ordem universal de valores agregados à utilidade social da ciência. Estes critérios, e a crítica à dependência intelectual e doutrinal, são equacionados por Luís António Verney sem as grilhetas de tudo o que subjuga o espírito na base da descoberta da verdade, legitimando as operações mentais do raciocínio e do discurso.Verney, Teodoro de Almeida, Frei Manuel do Cenáculo ou Ribeiro Sanches foram eruditos esclarecidos, contribuindo para a construção de um novo modelo de ensino, na sua forma e conteúdos, inserido na órbita ideária das Luzes. Apesar das diferentes concepções e posições, estes eruditos partilhavam do objectivo comum: a felicidade ser útil ao género humano, idealizando a contribuição da Filosofia e das ciências racionais como motor para a compreensão da natureza e do homem, preterindo a revelação divina à universalidade da razão natural.

A política cultural durante o regime do Marquês de Pombal tem uma face no ensino, como suporte para a difusão da boa educação, e outra, na censura, para controlo da opinião pública e defesa da ideologia do Estado. Em capítulos próprios, ficam evidentes as dinâmicas proporcionadas e vivificadas pela imprensa, na tripla função de cimentar o espaço reservado à opinião pública, de amplificar o exercício da crítica e de funcionar como agente de difusão cultural.

Ana Cristina Araújo seleccionou três jornais, o Anónimo (1752-1754), a Gazeta Literária (1761-1762) e o Jornal Enciclopédico (1779-1793), como case studies de curta vida, revelando o modus operandi, as preocupações, as temáticas abordadas, os apoios externos e internos, a singular inovação que representaram na segunda metade de setecentos. 
Simultaneamente, complexificam-se e diversificam-se estes mecanismos. Existem vários livreiros estrangeiros em Portugal, publicam-se obras de ciência moderna em língua portuguesa, proliferam os espaços dedicados a colecções de História Natural e a experiências científicas, promovem-se expedições e viagens científicas, nascem jardins botânicos e museus, inauguram-se as bibliotecas. A abertura de equipamentos culturais em finais de setecentos reflecte a necessidade social e cultural, também simbólica, das interacções de uma nova sociabilidade.

O panorama da relação de toda esta dinâmica com a censura, é objecto de análise transversal, evidenciando a sua volubilidade, com excepções e permissões, na repressão dos livreiros, nas opções editoriais, no controlo das importações e nos expedientes praticados, que denunciam as dificuldades de funcionamento e os paradoxos do aparelho censório no Portugal setecentista.

Uma referência final para a extensa bibliografia apresentada, cuja riqueza se oferece como fonte para o prolongamento do estudo de assuntos específicos ou a exploração de conteúdos vinculados à temática. Finalmente, A Cultura das Luzes em Portugal é, também, servida por um índice onomástico, secção essencial e imprescindível para posteriores consultas e estudos. 